\title{
Animal models of right heart failure
}

\author{
Asger Andersen ${ }^{1}$, Diederik E. van der Feen ${ }^{2}$, Stine Andersen ${ }^{1}$, Jacob Gammelgaard Schultz ${ }^{1}$, \\ Georg Hansmann ${ }^{3}$, Harm Jan Bogaard ${ }^{4}$
}

${ }^{1}$ Department of Cardiology, Aarhus University Hospital, Aarhus, Denmark; ${ }^{2}$ Center for Congenital Heart Diseases, University Medical Center Groningen, Groningen, The Netherlands; ${ }^{3}$ Department of Pediatric Cardiology and Critical Care, Hannover Medical School, Hannover, Germany; ${ }^{4}$ Amsterdam UMC, Vrije Universiteit Amsterdam, Pulmonary Medicine, Amsterdam Cardiovascular Sciences, Amsterdam, The Netherlands

Contributions: (I) Conception and design: All authors; (II) Administrative support: None; (III) Provision of study materials or patients: None; (IV) Collection and assembly of data: None; (V) Data analysis and interpretation: None; (VI) Manuscript writing: All authors; (VII) Final approval of manuscript: All authors.

Correspondence to: Asger Andersen, Department of Cardiology, Aarhus University Hospital, Palle Juul Jensens Boulevard 99, 8200 Aarhus, Denmark. Email: asger.andersen@clin.au.dk.

\begin{abstract}
Right heart failure may be the ultimate cause of death in patients with acute or chronic pulmonary hypertension (PH). As $\mathrm{PH}$ is often secondary to other cardiovascular diseases, the treatment goal is to target the underlying disease. We do however know, that right heart failure is an independent risk factor, and therefore, treatments that improve right heart function may improve morbidity and mortality in patients with PH. There are no therapies that directly target and support the failing right heart and translation from therapies that improve left heart failure have been unsuccessful, with the exception of mineralocorticoid receptor antagonists. To understand the underlying pathophysiology of right heart failure and to aid in the development of new treatments we need solid animal models that mimic the pathophysiology of human disease. There are several available animal models of acute and chronic PH. They range from flow induced to pressure overload induced right heart failure and have been introduced in both small and large animals. When initiating new pre-clinical or basic research studies it is key to choose the right animal model to ensure successful translation to the clinical setting. Selecting the right animal model for the right study is hence important, but may be difficult due to the plethora of different models and local availability. In this review we provide an overview of the available animal models of acute and chronic right heart failure and discuss the strengths and limitations of the different models.
\end{abstract}

Keywords: Pulmonary hypertension (PH); animal models; pulmonary heart disease; congenital heart defects; pulmonary embolism (PE)

Submitted Mar 30, 2020. Accepted for publication May 13, 2020.

doi: $10.21037 / \mathrm{cdt}-20-400$

View this article at: http://dx.doi.org/10.21037/cdt-20-400

\section{Introduction}

The right ventricle is a thin-walled structure and an increase in RV afterload, sudden or chronic, may induce RV failure. RV failure is the ultimate cause of morbidity and mortality in several cardiovascular conditions such as congenital heart disease, left heart disease, pulmonary hypertension $(\mathrm{PH})$, pulmonary valve disease, and acute pulmonary embolism (PE) (1,2). There are no current therapies that directly target or support the failing RV. There have been several attempts to develop therapies that directly support the failing RV, but the clinical translation has so far been unsuccessful and treatments that effectively improve the failing left heart do not seem to support the failing RV (3). As RV failure is often secondary to other cardiovascular conditions, the primary treatment goal is to treat the cause of RV failure. We know that RV function is an independent risk factor in many cardiopulmonary morbidities (4) and therefore, targeted therapy to improve RV function may improve overall morbidity and mortality in patients 


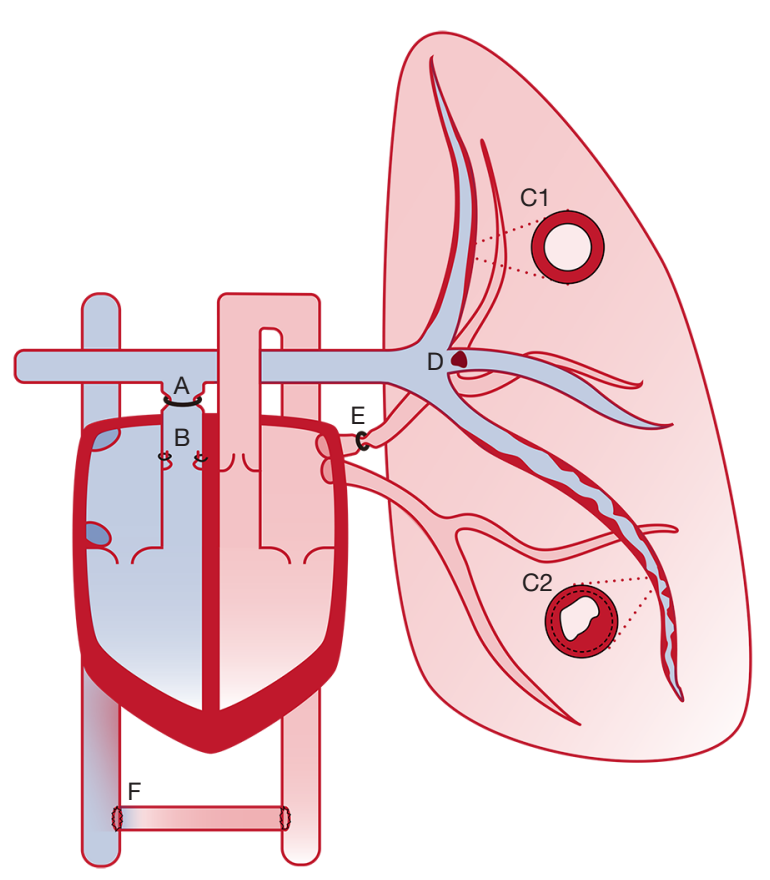

Figure 1 Overview of the targets for inducing right ventricular failure in animal models. A, pulmonary artery banding; B, pulmonary regurgitation; $\mathrm{C} 1$, mild pulmonary hypertension (monocrotaline, shunt, hypoxia, BMPR2-/-); C2, severe pulmonary hypertension (sugen + hypoxia, MCT + shunt); D, pulmonary embolism; E, pulmonary vein banding; F, aorto-caval shunt.

suffering from RV failure. To test current and new therapies and to conduct basic research for better understanding of the underlying pathophysiology in RV failure, we need solid and well-described animal models of RV failure. A plethora of animal models of RV failure exists and choosing the right model for the right experiment may be challenging. The aim of this review is to give an overview of the available models of RV failure and to provide the reader with strengths and limitations of the existing RV failure models.

\section{Animal models of RV failure}

RV failure can be caused by several entities. Figure 1 gives an overview of the targets for inducing RV failure in animal models. The different methods will be discussed in the following sections, and for each section there is a table with the animal models listed including strengths and limitations to the model and references to the animal species that the model have been introduced in.

\section{Acute RV failure}

The thin-walled RV is sensitive to acute increases in afterload. This causes acute RV failure induced by an abrupt increase in RV afterload in the majority of experimental models. Beside this common denominator, models of acute RV failure vary both in terms of the method of afterload increase, animal species, and hemodynamic phenotype. We focus on two main categories; Models of acute PE and models of acute transient pulmonary occlusion (Table 1).

\section{Models of acute PE}

Models of acute PE inject different materials to the pulmonary circulation, herby increasing pulmonary vascular resistance (PVR) and hence RV afterload and strain.

\section{Pharmacological PE models}

Pharmacological PE models use intravascular injections of drugs which cause blood coagulation and/or vasoconstriction. Most frequently used are thrombin (5), collagen combined with epinephrine (6), or adenosine diphosphate (10). To target the pulmonary circulation, drugs are injected in the jugular vein, the right heart, or directly into the pulmonary circulation. The latter models are more specific, but require right heart catheterization. These models are mainly used in rodents and the hemodynamic phenotype is often complete hemodynamic collapse and death within minutes of injection (6). The primary endpoint is often mortality, as hemodynamic efficacy is difficult to detect due to the massive thrombus burden. The models are simple and inexpensive, but require a high number of animals (49). More recent models have succeeded in creating a balanced phenotype of RV strain (7-9). Despite this, the pathophysiology of the models remains far from that of clinical PE.

\section{Artificial exogenous PE models}

Models of exogenous PE inject pre-formed thrombus material into the pulmonary circulation. The majority are based on artificial thrombus material such as glass beads or plastic spheres (11-20,50-52). While nonphysiological, these models create a predictable increase in PVR and RV strain. Furthermore, the afterload is consistent over time, as the materiel does not dissolve. The hemodynamic phenotypes vary from little or no RV strain to decompensated RV failure and shock depending on the afterload increase. Exogenous clot models are therefore 
Table 1 Models of acute right ventricular failure

\begin{tabular}{|c|c|c|c|c|c|c|c|c|}
\hline Method & Strengths & Limitations & Mouse & Rat & Rabbit & Dog & Sheep & Pig \\
\hline \multirow{2}{*}{$\begin{array}{l}\text { Pharmacological } \\
\text { coagulation } \\
\text { vasoconstriction }\end{array}$} & Feasible & Often fatal & $(5-9)$ & $(10)$ & & & & \\
\hline & Minimal instrumentation & $\begin{array}{l}\text { Difficult to control thrombus } \\
\text { load }\end{array}$ & & & & & & \\
\hline \multirow{2}{*}{$\begin{array}{l}\text { Exogenous clot } \\
\text { Artificial }\end{array}$} & Controllable thrombus burden & Only distal thrombus & & & & & & \\
\hline & Stable and lasting thrombus & Not able to remove thrombus & & & & & & \\
\hline \multirow[t]{2}{*}{$\begin{array}{l}\text { Exogenous clot } \\
\text { Autologous }\end{array}$} & Comparable to human physiology & $\begin{array}{l}\text { Thrombus created ex vivo- } \\
\text { Homogenous and fresh }\end{array}$ & & & $(21-24)$ & $(25-30)$ & $(18,31)$ & $(32-37)$ \\
\hline & Controllable thrombus load. & & & & & & & \\
\hline \multirow[t]{3}{*}{$\begin{array}{l}\text { Deep venous } \\
\text { thrombosis }\end{array}$} & $\begin{array}{l}\text { Thrombus created in vivo- } \\
\text { Heterogeneous and chronic }\end{array}$ & Challenging setup & & (38) & & & & (39) \\
\hline & Comparable to human physiology & $\begin{array}{l}\text { Time needed for thrombus } \\
\text { formation }\end{array}$ & & & & & & \\
\hline & Central thrombus & $\begin{array}{l}\text { Difficult to control thrombus } \\
\text { load. }\end{array}$ & & & & & & \\
\hline \multicolumn{9}{|c|}{ Pulmonary artery occlusion } \\
\hline $\begin{array}{l}\text { Pulmonary artery } \\
\text { banding }\end{array}$ & Precise afterload increase & Need for open chest & & (40) & $(41)$ & $(42)$ & $(43-45)$ & $(46,47)$ \\
\hline \multirow{3}{*}{$\begin{array}{l}\text { Pulmonary artery } \\
\text { balloon }\end{array}$} & Stable afterload & Unlike human physiology & & & & & & \\
\hline & Adjustable & & & & & & & \\
\hline & Wide range of RV strain & & & & & & & \\
\hline
\end{tabular}

An overview of models of RV failure stratified to method of afterload increase and animal species.

well-suited for evaluating RV function and interventions targeting the RV or systemic circulation. The concept has been implemented in a wide range of species varying from rodents to large animals. The artificial nature of the thrombus, however, differs from that of autologous PE. Firstly, artificial material does not possess the same vasoactive effects as an autologous thrombus. Secondly, the artificial materiel cannot be dissolved and does not allow for evaluations of interventions of thrombus removal.

\section{Autologous exogenous PE models}

Models of autologous PE all use a variation of the same technique. Blood is drawn from the animal, then set to coagulate ex vivo into an autologous thrombus, before it is re-injected to the pulmonary circulation as a $\mathrm{PE}$. The protocol for thrombus formation varies between 
models. While all models aim to create a PE similar to that found in patients, thrombi are still created ex vivo, and are not exposed to the continuous flow of substrates in the vein of a patient. The thrombi are therefore less heterogeneous, less rigid, and less fibrotic compared with a chronic thrombus from a patient (53). The thrombus size varies between models from small clots, which lodge distally (25,26,31-36,54), to large central PEs (37). The hemodynamic phenotype entails ranges of RV strain $(37,54)$ and decompensated RV failure (21-23). Models of autologous PE are well-suited for studies of RV function, but also of interventions focusing on the thrombus, both pharmacological treatments and, in the larger animal models (dog, sheep, pig), novel catheter directed therapies. The latter may prove important in preclinical evaluations of safety and efficacy in this promising new field (55).

\section{Deep venous thrombosis-PE models}

The models most true to that of clinical PE are based on in vivo thrombus formation. By occluding the inferior vena cava, models have succeeded in creating deep vein thrombosis (DVT), which can be released to travel via the blood stream to the pulmonary circulation (39). As the thrombus forms in vivo, over time, it is more heterogeneous and possibly more similar to that of a patient. The models are however associated with challenges. Instrumentation is more extensive and the DVT needs days to form, why experiments cannot be performed on the same day. Furthermore, it is not possible to control the thrombus size and hence the afterload increase and hemodynamic phenotype. Consequently, models have not been able to show RV strain. Studies on experimental DVT-PE are few and have to our knowledge only been implemented in rats (38) and pigs (39).

\section{Models of transient pulmonary artery occlusion}

Models of transient pulmonary artery occlusion increase $\mathrm{RV}$ afterload by mechanical constriction of the pulmonary artery from the exterior or by inflation of intravascular balloons (48). External occlusion can be applied by ligature $(43,44)$, snares $(42)$, simple banding $(40)$, or more advanced adjustable bands using air $(41,45,46)$. The occlusion, and hence the PVR and RV strain, can be adjusted very precisely and, as opposed to PE models, the resistance can be reduced or even removed as the occlusion can be re-loosened. As the mechanical occlusion is fixed at the level of the main pulmonary artery, the resistance of the more distal pulmonary circulation is less important. The models are therefore well-suited for studies of isolated RV function and not of pulmonary effects. A drawback of the models is the need for open chest protocols, which both increases instrumentation but also changes cardiovascular hemodynamics. Models exists in both rodents (40), rabbits (41), and large animals (42-45).

\section{Sustained pressure overload-induced RV failure}

Sustained pressure overload of the RV can induce failure. The right ventricle does not respond well to an abrupt increase in afterload (56) but with a chronic pressure overload the RV adapts well and it can adapt to systemic afterload for an extended period of time. Initially, the adaption to the increase in pressure is beneficial, but with sustained and increasing pressure overload, the RV will eventually fail (57). Sustained pressure overload of the RV is clinically seen in patients with $\mathrm{PH}$ and a $\mathrm{RV}$ outflow tract or pulmonary valve stenosis. In animal models, it is important to distinguish between models with a fixated $\mathrm{RV}$ afterload or not. The pulmonary artery banding model is a model with a fixated afterload making it suitable to evaluate interventions targeting RV function without worrying about the result being secondary to afterload reduction. Models of $\mathrm{PH}$ on the other hand are very well suited to evaluate treatments targeting the pulmonary circulation, but an improvement in RV function may be secondary to an afterload reduction and not caused by direct effects on the RV. The models are presented in the following and Table 2 .

\section{Pulmonary artery banding (PAB)}

$\mathrm{PAB}$ is a simple surgical procedure, where a band is tightened around the pulmonary artery to increase afterload. This induces sustained pressure overload and over time RV dysfunction and/or failure. In small animal models of rats and mice the most commonly used methods is a pre-adjusted hemostatic clip $(58,61-63)$ or a ligature tightened around the pulmonary artery $(59,60,64-66,96,97)$. Both methods works well, but the clip-method may be a bit faster to learn and more reproducible, whereas the ligature method does not introduce metal, making it more suitable for MRI or ultrasound evaluation of flow in the pulmonary artery. A challenge with the banding model have been to introduce RV failure and not just a well-adapted hypertrophic RV (98). The challenge is that in adult animals a tight band induces acute RV failure and death, but a looser band will never induce RV failure, but only compensated RV hypertrophy. To overcome this, most models introduce 
Table 2 Models of Sustained pressure overload induced right ventricular failure

\begin{tabular}{|c|c|c|c|c|c|c|c|c|c|}
\hline Method & Strengths & Limitations & Mouse & Rat & Rabbit & Dog & Sheep & Pig & Calves \\
\hline \multirow[t]{2}{*}{$\begin{array}{l}\text { Pulmonary artery } \\
\text { banding }\end{array}$} & Simple & $\begin{array}{l}\text { Abrupt initial afterload } \\
\text { increase }\end{array}$ & $(58-60)$ & $(61-66)$ & $(67-69)$ & $(70-72)$ & (73) & $(74-76)$ & \\
\hline & Reproducible & $\begin{array}{l}\text { Difficult to induce severe RV } \\
\text { failure }\end{array}$ & & & & & & & \\
\hline \multicolumn{10}{|c|}{ Pulmonary hypertension } \\
\hline \multirow[t]{2}{*}{ Monocrotaline } & Feasible & Myocarditis, large variation & & $(77-79)$ & & & & & \\
\hline & Simple & $\begin{array}{l}\text { No angio-obliterative } \\
\text { pulmonary lesions }\end{array}$ & & & & & & & \\
\hline \multirow[t]{3}{*}{$\begin{array}{l}\text { Monocrotaline + } \\
\text { pneumonectomy }\end{array}$} & $\begin{array}{l}\text { Angio-obliterative pulmonary } \\
\text { lesions }\end{array}$ & Myocarditis & & $(81)$ & & & & & \\
\hline & Decompensated RV failure & $\begin{array}{l}\text { Large same-strain animal } \\
\text { variation }\end{array}$ & & & & & & & \\
\hline & & Surgical procedure & & & & & & & \\
\hline Chronic hypoxia & $\begin{array}{l}\text { Stable response within } \\
\text { same-strain animals }\end{array}$ & $\begin{array}{l}\text { Only compensated RV } \\
\text { hypertrophy }\end{array}$ & (82) & (83) & & & & & (84) \\
\hline $\begin{array}{l}\text { Fawn-hooded } \\
\text { rats }\end{array}$ & $\begin{array}{l}\text { Chromosomal abnormality } \\
\text { similar to idiopathic PAH }\end{array}$ & $\begin{array}{l}\text { Limited to the fawn-hooded } \\
\text { rat }\end{array}$ & & $(88-90)$ & & & & & \\
\hline $\begin{array}{l}\text { Sugen in athymic } \\
\text { rats }\end{array}$ & $\begin{array}{l}\text { Lung pathophysiology } \\
\text { comparable to human PAH }\end{array}$ & $\begin{array}{l}\text { Development of RV failure } \\
\text { has not been described }\end{array}$ & & (91) & & & & & \\
\hline & & $\begin{array}{l}\text { Apoptosis of myocardial } \\
\text { microvascular endothelial } \\
\text { cells }\end{array}$ & & & & & & & \\
\hline $\begin{array}{l}\text { Chronic } \\
\text { thromboembolic } \\
\text { pulmonary } \\
\text { hypertension } \\
\text { (CTEPH) }\end{array}$ & $\begin{array}{l}\text { Mimics the hemodynamics } \\
\text { of CTEPH }\end{array}$ & $\begin{array}{l}\text { Not exact pathophysiologic } \\
\text { CTEPH }\end{array}$ & & (92) & & & & $(93-95)$ & \\
\hline
\end{tabular}

An overview of models of RV failure stratified to method of afterload increase and animal species. PAH, pulmonary arterial hyoertension; CTEPH, chronic thromboembolic pulmonary hypertension. 
the surgery in weanlings. By doing this, the stenosis will become relatively more severe as the animal grows and allow for severe RV failure over time.

Another advantage of the banding method is that the precise diameter of the band/clip allows for precise titration of afterload to induce RV hypertrophy, compensated RV failure, or decompensated RV failure $(61,99,100)$. As seen by hypertrophy with preserved hemodynamics, altered hemodynamics, but no extracardiac signs of RV failure, and altered hemodynamics with extracardiac signs of RV failure. The larger animal models of PAB have been described in rabbits (67-69), dogs (70-72), swine (74,75), and sheep $(44,101)$. Advantage of large animal models over small animal models in RV failure is predominantly the more "human like" anatomy of the larger animals making more refined surgical methods for banding possible. This allows for bands that can be adjusted $(73,75,102,103)$ over time, an obstructing balloon instead of a band (104), and removal of band to investigate reverse RV remodeling (71).

\section{Hypoxia}

Chronic hypoxia (usually $\mathrm{FiO}_{2} 10 \%$ or 0.5 atmospheric pressure, for 3 weeks) has been used to induce $\mathrm{PH}$ in various animal species for decades (82-84). Exposure to hypoxia cause transient muscularization and thickening of the smaller pulmonary arteries (105) accompanied by an inflammatory response (106). RV function is, however, well preserved under hypoxic conditions (107).

PH caused by chronic hypoxia (group 3.4 PH "hypoxia without lung disease") (108) only induces compensated RV hypertrophy, but no RV dilation, and is transient, i.e., RV and PA pressure, and peripheral PA muscularization turn back to normal within days when animals are returned to room air. Accordingly, the chronic hypoxia model is not a model of RV dysfunction or failure, and not a model of $\mathrm{PAH}$.

The response to chronic hypoxia varies significantly with age, where younger animals with more immature lungs seems much more susceptible to develop severe vascular injuries (84). The response also varies among species, where rats develop more severe $\mathrm{PH}$ when exposed to hypoxia compared with for example mice (105). The most severe response is observed in Fawn-hooded rats (88). Due to defect pulmonary vascular oxygen sensing, they develop severe $\mathrm{PH}$ under hypoxic conditions and even under normoxic conditions changes in pulmonary pressures occurs in these rats $(89,90)$.

Specific genetic animal models may yield protection or aggravation of chronic hypoxia-induced $\mathrm{PH}$, and thus chronic hypoxia may be used in the phenotyping of such genetic models (109).

However, the aforementioned normalization of $\mathrm{PH}$ and pulmonary vascular remodeling after the end of chronic hypoxia, and the limited food and fluid intake during hypoxia (dehydration) are major limitation to the chronic hypoxia model. It should also be noted that chronic hypoxia drastically changes the mRNA expression profile in rat RV even several weeks after the return to normoxia (110), highlighting that rodent models involving hypoxia, i.e., chronic hypoxia-mediated $\mathrm{PH}$ or Sugen-Hypoxia $(\mathrm{SuHx}-$ PAH; see below under 2.2.4), should include a vehiclechronic hypoxia control group (110).

\section{Monocrotaline (MCT) in rats}

In the 1960s, it was shown that ingestion of the Crotalaria spectabilis seeds (MCT) induced $\mathrm{PH}$ in rats (77). Today, a subcutaneous injection of $60 \mathrm{mg} / \mathrm{kg}$ is the most common way to administer MCT (78). After oxidization in the liver to its active metabolite, MCT induces pulmonary endothelial cell damage and vasculitis (111), and during the following weeks $\mathrm{PH}$ and associated RV hypertrophy and failure develop.

Its methodological simplicity and low cost compared with other PH models makes the MCT model an appealing model, but its translatability is very limited. In addition to pulmonary effects, MCT also causes myocarditis evident by infiltration of inflammatory cells in the RV and LV myocardium $(112,113)$. These direct cardiac effects are a major limitation when the model is used in RV failure research.

Others questioned the suitability of the MCT model as a preclinical model of pulmonary arterial hypertension (PAH) based on the absence of plexiform lesions and occurrence of pulmonary venous changes (105). On the contrary, angio-obliterative pulmonary lesions develop in MCT rats with increased right pulmonary blood flow after left pneumonectomy and in MCT rats subjected to hypoxia, and these 2-hit-models may provide better alternatives to the single-hit MCT model $(80,81)$.

\section{Sugen hypoxia $(\mathrm{SuHx})$ in rats}

The SuHx rat model is a 2-hit model, where a single subcutaneous injection with the VEGF-receptor antagonist Sugen 5416 is followed by 3-4 weeks of hypoxia (86). The resulting endothelial hyperproliferation leads to progressive pulmonary vascular occlusion even after return to normoxia 
and RV systolic pressures of approximately $75(65-100 \mathrm{mmHg})$ $(87,114,115)$.

Severe $\mathrm{PH}$ is confirmed 1 week after return to normoxia, in the absence of significant RV dysfunction, but then systolic and diastolic RV dysfunction develops and RV failure is evident after another 5 weeks ( 6 weeks after the end of 3 weeks hypoxia) (110). A linear relationship between RV systolic pressure/RV hypertrophy and the density of occluded pulmonary vessels confirms, that the development of increased RV pressures and RV hypertrophy in this model is indeed caused by the pulmonary vascular changes and not direct cardiac effects of Sugen 5416 and/or hypoxia (116). Compared with rats exposed to hypoxia alone, $\mathrm{SuHx}$ rats develop decompensated RV failure (elevated RVEDP, RV dilation and decreased RVEF by cardiac MRI) (110) with maladaptive RV remodeling. Moreover pulmonary vascular lesions (concentric hypertrophic and plexiform) have been reported in this model $(86,110,117)$, and accordingly the SuHx model is generally considered the rat model resembling human PAH and associated RV failure the best $(114,118)$. Another approach that resembles the changes seen in SuHx is pneumonectomy in combination with sugen 5416 (119). This raises the question on whether the changes in the SuHx model are caused by hypoxia alone or if they are induced by the increase in shear- and radial stress secondary to hypoxic vasoconstriction.

\section{Sugen normoxia in athymic rats}

Athymic nude rats lacking T cellsdevelop PH and associated RV hypertrophy after subcutaneous Sugen 5416 injection (10-20 mg/kg/body weight) even without exposure to hypoxia, although RV (dys) function has not been assessed in this model (91). Preliminary experimental work indicates that these rats rapidly develop RV failure, as assessed by echocardiography and cardiac MRI, associated with high mortality (G. Hansmann, unpublished observation).

The lack of $T$ regulatory cells and the surge of leukotriens have been propsed as major drivers of the pathobiology in the athymic SuNx rat model and (91) the model have been used to prove the involvement of macrophage derived leukotriene A4 hydrolase in the development of $\mathrm{PH}$ (120).

\section{Sugen hypxoxia in mice}

Weekly Sugen 5416 injections during exposure to hypoxia cause $\mathrm{PH}$ in mice, but despite persistent $\mathrm{PH}$, progressive RV failure and pulmonary occlusive lesions are lacking during long-term follow-up $(85,121)$, and a reliable wild type murine model resembling the progressive development of pulmonary vascular lesions and RV failure in PAH patients still needs to be established.

A recent systematic review of animal models of $\mathrm{PH}$ including almost 300 publications recapitulated that the chronic hypoxia model is characterized by the lowest increase in RV systolic pressure and hypertrophy compared with the other models (122). The most severe response occurs in the SuHx model. Comparing MCT and SuHx rats, MCT rats have a much higher mortality despite similar degrees of RV dysfunction and lower mPAP in the MCT rats, suggesting that other factors contribute to disease progression and death in the MCT model (78). Although the response to chronic hypoxia varies significantly across species, it is consistent within a selected animal strain. For example the response to hypoxia is much more pronounced in rats compared with mice (122). On the contrary, the response to MCT injection varies significantly among even same-strain animals, probably due to differences in hepatic metabolism $(82,105)$.

\section{Chronic thromboembolic PH (CTEPH)}

CTEPH is a disease that develops from unresolved acute PE or in situ thrombus formation that obstruct the pulmonary vessels (123). The severity of disease is not only dependent on the mechanical obstruction of the chronic clots but also of the small vessel disease that follows $(124,125)$. The underlying pathophysiology is not fully understood, and the causes of CTEPH seems to be multifactorial. Repeated thromboembolic events, coagulopathies, and inflammation all seem to be involved in the development of CTEPH (126). The lack of pathobiological understanding of CTEPH makes the available animal models limited, but it also underlines the importance of developing new animal models, as they can improve our understanding of this disease. Several attempts have been made to develop a model of CTEPH, but the early models did not succeed in replicating CTEPH due to clot lysis or the absence of $\mathrm{PH}$ and RV failure despite inhibition of clot lysis and the presence of chronic thrombi (127-130). Newer models have succeeded in mimicking the hemodynamic characteristics of CTEPH. One model of CTEPH ligate the left pulmonary artery followed by weekly injection of histoacryl in the artery of the right lower lobe for 5 weeks (93). Another model induces a percutaneously placed cobber scaffold followed by embolization and tranexamic acid (94). Despite successful mimicking the hemodynamics of CTEPH, they do not mimic the pathophysiology or -biology of CTEPH. 
Rat and pig models of microspheres in combination with thrombin, the tyrosine kinase inhibitor SU5416, or nitric oxide synthase (NOS) inhibition induced $\mathrm{PH}, \mathrm{RV}$ hypertrophy, and thickening of the pulmonary arteries suggesting more accurate CTEPH models, but a limitation in these models is the use of microbeads, not autologous blood clots $(92,95)$. The available CTEPH models are very useful for describing pathophysiology changes with increasing $\mathrm{RV}$ afterload to investigate interventions that may limit microvascular disease, and the researchers should be complemented for developing these elaborate models, but to fully understand the underlying pathophysiology and -biology of CTEPH we need more animal models that truly mimics CTEPH.

\section{Volume overload-induced $R$ V failure}

RV volume overload occurs in three main clinical entities: (I) pulmonary regurgitation due to pulmonary valve insufficiency or as occurs frequently in repaired Tetralogy of Fallot (ToF) (131,132); (II) tricuspid regurgitation (133); (III) pre-tricuspid shunts such as atrial septal defects (ASDs). Post-tricuspid shunts such as ventricular septal defects (VSDs) also cause RV volume overload, but with an increased pressure load component due to high LV systolic pressures and the relatively rapid development of shunt-induced PAH (134). Volume overload-associated $\mathrm{RV}$ failure is a growing concern especially in repaired ToF, now survival of these patients throughout childhood has improved (132). However, the pathology of RV volume load and its treatment are relatively unexplored area of research, and experimental data in animal models is warranted (135). The available animal models for RV volume overload are (I) the aorto-caval shunt model, and (II) the pulmonary regurgitation model. A model for tricuspid regurgitation has also been described in dogs, but RV volume load was not assessed (136) (Table 3).

\section{Aorto-caval shunt}

The aorto-caval shunt model has been described in mice (153), rats $(137,138,144,153,154)$, pigs $(155)$, and dogs $(152)$. The rat is the predominant species. Shunt surgery in rats is a relatively simple and quick (20 minutes) procedure, of which a detailed step-by-step protocol and a video are available (139). In a meta-analysis of 145 shunted animals of multiple species, aorto-caval shunt surgery consistently led to increased end-diastolic and end-systolic volume and area, increased cardiac output, and stroke volume, indicating volume load. RV dP/dt max also increased, indicating increased contractility, probably due to the Frank-Starling mechanism (135). TAPSE and RV ejection fraction did not differ in shunted animals versus controls, and also did not deteriorate over time (up to 90 days), suggesting that RV failure does not occur in shunted animals. However, metaregression analysis did indicate that the early rise in cardiac output as a result of the shunt decreases after 90 days, suggesting a trend towards RV dysfunction. RV end diastolic pressure, a surrogate for RV dysfunction also increased in shunted animals versus controls. RV hypertrophy was observed in all shunted animals, and was consistently reported as an early response phenomenon, with no progression during prolonged shunting. Myocardial fibrosis was only observed in shunted animals after 90 days (135). When using the aorto-caval shunt model to study isolated $\mathrm{RV}$ volume overload, it is important to realize that these models may also induce $\mathrm{PH}$ (thus RV pressure load) over time, due to chronic pulmonary overcirculation (156). The addition of a pressure component to RV load is associated with a distinctly different hemodynamic and molecular RV adaptation profile (137). It is advisable therefore to rule out the presence of $\mathrm{PH}$ by measuring pulmonary artery pressures.

\section{Pulmonary valve regurgitation}

The pulmonary regurgitation, or pulmonary valve insufficiency model has been characterized predominantly in pigs (76,157-162), but also in sheep (163) and mice (164). Pulmonary regurgitation is created by placing sutures through the wall of the pulmonary trunk around the hinge points of the pulmonary valve leaflets (157). In a meta-analysis of 135 animals, pigs mostly, pulmonary regurgitation surgery led to increased end-diastolic and endsystolic volume and area, indicating RV volume load (135). $\mathrm{RV}$ stroke volume was also increased, but cardiac output and ejection fraction were unchanged. Pulmonary regurgitation fraction was increased. RV contractility, expressed as $\mathrm{RV}$ preload recruitable stroke work (PRSW) and RV end-systolic pressure-volume relation (ESPVR), were significantly decreased, and RV end-diastolic pressure was increased in regurgitation animals compared to controls, suggesting RV dysfunction. Like in the shunted animals, RV hypertrophy was observed early ( $<90$ days) after surgery and did not appear to increase further with longer duration of the study. Myocardial fibrosis was reported only after 90 
Table 3 Models of combined volume and pressure overload

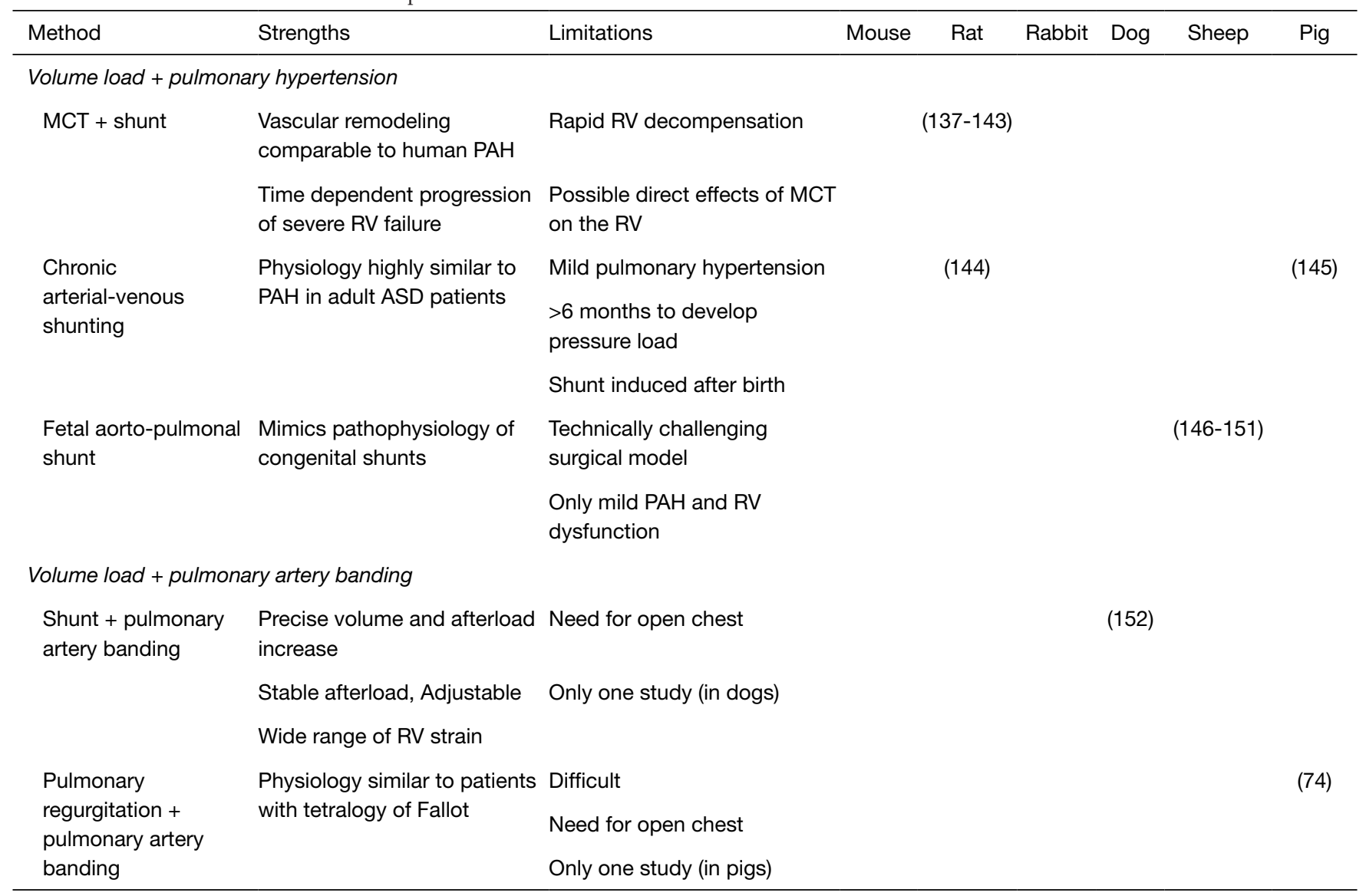

An overview of models of Models of combined volume and pressure overload stratified to method of combined load increase and animal species. PAH, pulmonary arterial hypertension; MCT, monocrotaline.

days of volume overload (135).

\section{Combined volume- and pressure overload-induced $R V$ failure}

A typical clinical example of combined RV volume and pressure overload can be found in patients with $\mathrm{PAH}$ due to a congenital cardiac left-to-right shunt (PAHCHD). In these patients, the volume load is congenital and pressure load develops progressively due to increasing PVR as a result of pulmonary vascular remodeling (134). Although PAH is primarily a disease of the pulmonary vasculature, the state of the $\mathrm{RV}$ is the main determinant of survival (165). In PAH patients both with and without a shunt, the severity of RV failure is determined primarily by the degree of pressure overload and has been correlated closely to PVR (165). The contribution to RV failure of the additional volume overload component in shuntassociated PAH is considerably less studied (137). During pressure load, increased preload may help to maintain adequate stroke volume via the Frank-Starling mechanism (79). However, combined loading conditions have also been associated with worse RV function and outcome in chronic settings (137). An alternative example of combined volume and pressure load is found in patients with repaired ToF, who often have residual pulmonary regurgitation as well as pulmonary branch stenosis: a combination that frequently leads to RV failure (74). Animal models for combined RV volume and pressure overload that mimic the conditions above can be categorized as: (I) shunt $+\mathrm{PH}$ induced by MCT or chronic overcirculation (PH), (II) shunt + PAB and (III) pulmonary regurgitation $+\mathrm{PAB}$. The available models are listed in Table 2 and reviewed below. 


\section{Shunt + PH}

\section{Aorto-caval shunt + monocrotaline}

The MCT+ aorto-caval Shunt model in rats was originally developed as a 'double hit' alternative to the MCT-only model. MCT-only rats lack so-called neointimal pulmonary vascular lesions that are characteristic of severe group 1 PAH $(156,166)$. It was demonstrated that the addition of increased pulmonary blood flow to MCT does lead to neointimal lesions and a more severe, progressive form of PAH $(81,167)$, making it more relevant to human PAH. The MCT + Shunt model in rats combines a $60 \mathrm{mg} / \mathrm{kg}$ injection of monocrotalin at day 0 with the surgical construction of an aorto-caval shunt at day 7 (139). The shunt is created by inserting an $18 \mathrm{G}$ needle from the abdominal aorta into the adjacent caval vein, leading to pulmonary overcirculation and RV volume overload. The combination of MCT and the shunt leads to neomuscularization of the pulmonary arterioles at day 14, the formation of occlusive neointimal lesions from day 21 , and RV failure around day 28 , followed by death from day 28 to 35 (138-140). The shunt increases RV cardiac output two-to-three fold, as well as TAPSE. From day 21, occlusive vascular remodeling causes the PVR to rise, resulting in an increase in systolic RVP up to $60 \mathrm{mmHg}$ and a decrease in pulmonary artery acceleration time. From day 21-35 TAPSE and cardiac output decrease progressively and RV hypertrophy occurs (138-140). The MCT + Shunt model has been implemented primarily to investigate new treatment strategies for pulmonary vascular disease, but can also be used to study combined volume and pressure overload of the RV, especially when PAB-, MCTor Shunt-only rats are used additionally as a control or to compare different loading conditions $(137,141)$. In a direct comparison with MCT-only or Shunt-only, MCT + Shunt results in a significantly compromised RV contractility, worse RV diastolic function, increased RV hypertrophy and more clinical signs of RV failure. Combined overload also had a strong additive effect on MYH-isoform switch, associated with pathologic RV remodeling (137).

\section{Chronic shunting models}

Chronic shunting leads to RV volume overload and secondary pulmonary hypertension, albeit mild. After 20 weeks, adult rats with an aorto-caval shunt show an increase in mPAP up to $40 \mathrm{mmHg}$ indicating increased afterload. Parameters for RV systolic and diastolic function, such as $\mathrm{dP} / \mathrm{dtMAX}, \mathrm{PRSW}$, and Tau were also decreased after 20 weeks, but symptoms of RV failure were not observed (144). Aorto-caval shunt in pigs leads to an increase in mPAP from 10 to $15 \mathrm{mmHg}$ after 5 weeks (145). The pulmonary vascular histology in chronic shunting adult animals is characterized by mild medial hypertrophy, resembling an early, reversible stage of $\mathrm{PAH}$ associated with pre-tricuspid shunts $(134,144)$.

\section{Fetal aorto-pulmonal shunt}

An in utero aorto-pulmonary shunt model in lambs induces chronic overflow through the pulmonary vascular bed mimicking the induction of PAH seen in several congenital heart conditions (146). This induces hyperproliferation of the pulmonary artery smooth muscle cells (147), alters the redox environment (168), induces vascular dysfunction independently of the NO-cGMP pathway (148), and induces a sustained increase in pulmonary artery resistance (146). The phenotype in this model is mild $\mathrm{PAH}$ and RV dysfunction, but it is a solid animal model for investigating the mechanisms involved in congenital overflow induced PAH (149-151,169,170).

\section{Shunt + PAB}

One study in dogs induced chronic RV volume overload by a bifemoral arteriovenous shunt. The shunts were closed after 3 months and then RV pressure load was created by PAB. The arteriovenous shunts increased cardiac output by $30 \%$, and RVSP from 25 to $34 \mathrm{mmHg}$, but RV systolic or diastolic function were not changed compared to non-shunted controls (152). Both shunted and nonshunted dogs were able to sustain a stable cardiac output after PAB. However, non-shunted controls responded to $\mathrm{PAB}$ by increasing contractility, whereas in shunted dogs contractility did not increase and cardiac output relied on the Frank-Starling mechanism as a primary adaptation to increased afterload.

\section{Pulmonary regurgitation + PAB}

In pigs, a combination of RV tract enlargement by transvalvular patch (volume overload via pulmonary regurgitation) and $\mathrm{PAB}$, induced an increase in $\mathrm{RV}$ peak pressure to around $60 \mathrm{mmHg}$ after 4 months, compared to $16 \mathrm{mmHg}$ in non-operated controls. End-systolic and enddiastolic volumes were higher and ejection fraction was lower in operated pigs. These hemodynamic changes were also associated by cardiac fibrosis myocyte hypertrophy and inflammation (74).

\section{Other genetic models of $\mathrm{PAH}$ and $\mathrm{RV}$ dysfunction}

Intriguing genetic models have increased our knowledge about important pathophysiological mechanisms in 
the development of RV failure and $\mathrm{PH}$ (171) including bone morphogenetic peptide receptor type 2 (BMPR-2) knockout mice (172), low-density lipoprotein receptorrelated protein 1 (LRP1) deficient mice (173), and insulinresistant male apoE-deficient mice (174). TGF- $\beta 1$ transgenic mice with heightened level of circulating TGF- $\beta 1$ show pulmonary vascular remodeling and increased RV pressure in room air (175), and stimulation of the peroxisome proliferator-activated receptor gamma (PPAR $\gamma$ ) by oral pioglitazone downstream of the BMP2 receptor reversed $\mathrm{PH}$ in these TGF- $\beta 1$ transgenic mice. In this work, PPAR $\gamma$ has been identified as a link between the anti-proliferative BMP2 and the proliferative TGF- $\beta$ signaling pathways in vascular SMC known to be dysbalanced in human PAH (175).

Mice with targeted deletion of PPAR $\gamma$ in smooth muscle cells spontaneously developed PAH (176). Moreover, selective deletion of PPAR $\gamma$ in cardiomyocytes leads to biventricular systolic dysfunction in mice underlining the centralbeneficial role of PPAR $\gamma$ not only in PH lungs but also RV dysfunction $(110,177)$.

\section{Future directions}

There is a plethora of animals models of acute and chronicprogressive RV dysfunction and failure. To ensure the best translation from bench to bedside we advocate that the researcher carefully select the animal model that is best suited to the research question at hand. In this review we present the available animal models for RV failure. We do, however, still need to refine and develop animal models of RV failure to create more precise pathophysiologic- and biologic modeling to ensure the best possible pre-clinical research and successful clinical translation (178-181).

\section{Acknowledgments}

Funding: None.

\section{Footnote}

Provenance and Peer Review: This article was commissioned by the Guest Editors (Martin Koestenberger, HarmJan Bogaard and Georg Hansmann) for the series "Right Ventricular Dysfunction" published in Cardiovascular Diagnosis and Therapy. The article was sent for external peer review organized by the Editor-in-Chief and the editorial office.
Conflicts of Interest: All authors have completed the ICMJE uniform disclosure form (available at http://dx.doi. org/10.21037/cdt-20-400). The series "Right Ventricular Dysfunction" was commissioned by the editorial office without any funding or sponsorship. GH and HJB served as the unpaid Guest Editors of the series. AA reports grants from Alfred Benzons Foundation, outside the submitted work. GH reports grants from German Research Foundation (DFG; HA4348/2-2 and HA4348/62 KFO311), grants from the Federal Ministry of Education and Research (BMBF ViP+ program-03VP08053; BMBF $01 \mathrm{KC} 2001 \mathrm{~B})$, grants from the European Pediatric Pulmonary Vascular Disease Network (www.pvdnetwork. org), outside the submitted work. HJB reports grants from Dutch Cardiovascular Research Alliance, from null, outside the submitted work. The authors have no other conflicts of interest to declare.

Ethical Statement: The authors are accountable for all aspects of the work in ensuring that questions related to the accuracy or integrity of any part of the work are appropriately investigated and resolved.

Open Access Statement: This is an Open Access article distributed in accordance with the Creative Commons Attribution-NonCommercial-NoDerivs 4.0 International License (CC BY-NC-ND 4.0), which permits the noncommercial replication and distribution of the article with the strict proviso that no changes or edits are made and the original work is properly cited (including links to both the formal publication through the relevant DOI and the license). See: https://creativecommons.org/licenses/by-nc-nd/4.0/.

\section{References}

1. Haddad F, Doyle R, Murphy DJ, et al. Right ventricular function in cardiovascular disease, part II: pathophysiology, clinical importance, and management of right ventricular failure. Circulation 2008;117:1717-31.

2. Konstantinides SV, Torbicki A, Agnelli G, et al. 2014 ESC guidelines on the diagnosis and management of acute pulmonary embolism. Eur heart J 2014;35:3033-69, 3069a-3069k.

3. Reddy S, Bernstein D. Molecular Mechanisms of Right Ventricular Failure. Circulation 2015;132:1734-42.

4. Haddad F, Hunt SA, Rosenthal DN, et al. Right Ventricular Function in Cardiovascular Disease, Part I: Anatomy, Physiology, Aging, and Functional Assessment 
of the Right Ventricle. Circulation 2008;117:1436-48.

5. Kumada T, Dittman WA, Majerus PW. A role for thrombomodulin in the pathogenesis of thrombin-induced thromboembolism in mice. Blood 1988;71:728-33.

6. Konstantinides S, Schäfer K, Neels JG, et al. Inhibition of endogenous leptin protects mice from arterial and venous thrombosis. Arterioscler Thromb Vasc Biol 2004;24:2196-201.

7. Tymvios C, Jones S, Moore C, et al. Real-time measurement of non-lethal platelet thromboembolic responses in the anaesthetized mouse. Thromb Haemost 2008;99:435-40.

8. Brandt M, Giokoglu E, Garlapati V, et al. Pulmonary Arterial Hypertension and Endothelial Dysfunction Is Linked to NADPH Oxidase-Derived Superoxide Formation in Venous Thrombosis and Pulmonary Embolism in Mice. Oxid Med Cell Longev 2018;2018:1860513.

9. Rauzi F, Smyth E, Emerson M. Refinement of Mouse Protocols for the Study of Platelet Thromboembolic Responses In Vivo. Thromb Haemost 2017;117:2283-90.

10. Nordoey A, Chandler AB. Platelet thrombosis induced by adenosine diphosphate in the rat. Scand J Haematol 1964;1:16-25.

11. Watts JA, Gellar MA, Fulkerson MBK, et al. Pulmonary vascular reserve during experimental pulmonary embolism: Effects of a soluble guanylate cyclase stimulator, BAY 418543*. Crit Care Med 2011;39:2700-4.

12. Zagorski J, Kline JA. Differential effect of mild and severe pulmonary embolism on the rat lung transcriptome. Respir Res 2016;17:86.

13. Jones AE, Watts JA, Debelak JP, et al. Inhibition of prostaglandin synthesis during polystyrene microsphereinduced pulmonary embolism in the rat. Am J Physiol Lung Cell Mol Physiol 2003;284:L1072-81.

14. Nilsson KF, Gustafsson LE, Adding LC, et al. Increase in exhaled nitric oxide and protective role of the nitric oxide system in experimental pulmonary embolism. Br J Pharmacol 2007;150:494-501.

15. Yang GF, Yang X, Zhang LJ, et al. Pulmonary Enhancement Imaging with Dual Energy CT for the Detection of Pulmonary Embolism in a Rabbit Model: Comparison to Perfusion Planar Scintigraphy, SPECT and SPECT-CT Modalities. Acad Radiol 2011;18:605-14.

16. Dias-Junior CA, Tanus-Santos JE. Hemodynamic effects of sildenafil interaction with a nitric oxide donor compound in a dog model of acute pulmonary embolism. Life Sci 2006;79:469-74.
17. Lagos-Carvajal AP, Teixeira-Neto FJ, Becerra-Velásquez $\mathrm{DR}$, et al. Adrenomedullin induces pulmonary vasodilation but does not attenuate pulmonary hypertension in a sheep model of acute pulmonary embolism. Life Sci 2015;139:139-44.

18. Sertório JT, Neto-Neves EM, Dias-Junior CA, et al. Elevated Plasma Hemoglobin Levels Increase Nitric Oxide Consumption in Experimental and Clinical Acute Pulmonary Thromboembolism*. Crit Care Med 2013;41:e118-24.

19. Tsang JYC, Lamm WJE, Starr IR, et al. Spatial pattern of ventilation-perfusion mismatch following acute pulmonary thromboembolism in pigs. J Appl Physiol 2005;98:1862-8.

20. Böttiger BW, Motsch J, Dörsam J, et al. Inhaled Nitric Oxide Selectively Decreases Pulmonary Artery Pressure and Pulmonary Vascular Resistance Following Acute Massive Pulmonary Microembolism in Piglets. Chest 1996;110:1041-7.

21. Chen HM, Duan YY, Li J, et al. A rabbit model with acute thrombo-embolic pulmonary hypertension created with echocardiography guidance. Ultrasound Med Biol 2008;34:221-7.

22. Wang Y, Yu D, Yu Y, et al. Potential role of sympathetic activity on the pathogenesis of massive pulmonary embolism with circulatory shock in rabbits. Respir Res 2019;20:97.

23. Yu D, Wang Y, Yu Y, et al. Acute Beneficial Effects of Sodium Nitroprusside in a Rabbit Model of Massive Pulmonary Embolism Associated with Circulatory Shock. Am J Pathol 2018;188:1768-78.

24. Zhang Z, Meng Z, Wang Y. Correlations of inhaled NO with the c'TnI levels and the plasma clotting factor in rabbits with acute massive pulmonary embolism. Acta Cir Bras 2018;33:664-72.

25. Feng JH, Li WM, Wu XP, et al. Hemodynamic effect of apelin in a canine model of acute pulmonary thromboembolism. Peptides 2010;31:1772-8.

26. Dias-Junior CAC, Gladwin MT, Tanus-Santos JE. Lowdose intravenous nitrite improves hemodynamics in a canine model of acute pulmonary thromboembolism. Free Radic Biol Med 2006;41:1764-70.

27. Lee JH, Chun YG, Lee IC, et al. Pathogenic role of endothelin 1 in hemodynamic dysfunction in experimental acute pulmonary thromboembolism. Am J Respir Crit Care Med 2001;164:1282-7.

28. Ewalenko P, Brimioulle S, Delcroix M, et al. Comparison of the effects of isoflurane with those of propofol on pulmonary vascular impedance in experimental embolic 
pulmonary hypertension. Br J Anaesth 1997;79:625-30.

29. Zhao LB, Jia ZY, Lu GD, et al. Establishment of a canine model of acute pulmonary embolism with definite right ventricular dysfunction through introduced autologous blood clots. Thromb Res 2015;135:727-32.

30. Zhang Y, Liu H, Zhang Y, et al. Efficacy evaluation of reteplase in a novel canine acute pulmonary thromboembolism model developed by minimally invasive surgery and digital subtraction angiography. Drug Des Devel Ther 2018;12:3717-30.

31. Neto-Neves EM, Dias-Junior CA, Uzuelli JA, et al. Sildenafil improves the beneficial hemodynamic effects exerted by atorvastatin during acute pulmonary thromboembolism. Eur J Pharmacol 2011;670:554-60.

32. Kjaergaard B, Kristensen SR, Risom M, et al. A porcine model of massive, totally occlusive, pulmonary embolism. Thromb Res 2009;124:226-9.

33. Pereira DJ, Moreira MM, Paschoal IA, et al. Nearfatal pulmonary embolism in an experimental model: hemodynamic, gasometric and capnographic variables. Rev Bras Cir Cardiovasc 2011;26:462-8.

34. Aagaard R, Caap P, Hansson NC, et al. Detection of Pulmonary Embolism During Cardiac Arrest Ultrasonographic Findings Should Be Interpreted With Caution. Crit Care Med 2017;45:e695-702.

35. Nakazawa K, Tajima H, Murata S, Kumita S-I, et al. Catheter fragmentation of acute massive pulmonary thromboembolism: distal embolisation and pulmonary arterial pressure elevation. Br J Radiol 2008;81:848-54.

36. Lee JH, Kim S, Park BK, et al. The effect of a combination of inhaled nitric oxide and an endothelinAreceptor antagonist on hemodynamic dysfunction in experimental acute pulmonary thromboembolism. Lung 2005;183:139-49.

37. Schultz J, Andersen A, Gade IL, et al. A porcine invivo model of acute pulmonary embolism. Pulm Circ 2018;8:2045893217738217.

38. Rectenwald JE, Deatrick KB, Sukheepod P, et al. Experimental pulmonary embolism: effects of the thrombus and attenuation of pulmonary artery injury by low-molecular-weight heparin. J Vasc Surg 2006;43:800-8.

39. Barbash IM, Schenke WH, Halabi M, et al. Experimental model of large pulmonary embolism employing controlled release of subacute caval thrombus in swine. J Vasc Interv Radiol 2011;22:1471-7.

40. Cao Y, Song J, Shen S, et al. Trimedazidine alleviates pulmonary artery banding-induced acute right heart dysfunction and activates PRAS40 in rats. Oncotarget
2017;8:92064-78.

41. Apitz C, Honjo O, Friedberg MK, et al. Beneficial effects of vasopressors on right ventricular function in experimental acute right ventricular failure in a rabbit model. Thorac Cardiovasc Surg 2012;60:17-23.

42. Kerbaul F, Rondelet B, Motte S, et al. Effects of norepinephrine and dobutamine on pressure load-induced right ventricular failure. Crit Care Med 2004;32:1035-40.

43. Hon JK, Steendijk P, Khan H, et al. Acute effects of pulmonary artery banding in sheep on right ventricle pressure-volume relations: relevance to the arterial switch operation. Acta Physiol Scand 2001;172:97-106.

44. Yerebakan C, Klopsch C, Niefeldt S, et al. Acute and chronic response of the right ventricle to surgically induced pressure and volume overload--an analysis of pressure-volume relations. Interact Cardiovasc Thorac Surg 2010;10:519-25.

45. Malinowski M, Proudfoot AG, Eberhart L, et al. Large animal model of acute right ventricular failure with functional tricuspid regurgitation. Int J Cardiol 2018;264:124-9.

46. Schmitto JD, Doerge H, Post H, et al. Progressive right ventricular failure is not explained by myocardial ischemia in a pig model of right ventricular pressure overload. Eur J CardioThorac Surg 2009;35:229-34.

47. Greyson C, Xu Y, Lu L, et al. Right ventricular pressure and dilation during pressure overload determine dysfunction after pressure overload. Am J Physiol Heart Circ Physiol 2000;278:H1414-20.

48. Kudlička J, Mlček M, Hála P, et al. Pig model of pulmonary embolism: where is the hemodynamic break point? Physiol Res 2013;62 Suppl 1:S173-9.

49. Miao R, Liu J, Wang J. Overview of mouse pulmonary embolism models. Drug Discov Today Dis Models 2010;7:77-82.

50. Roehl AB, Steendijk P, Baumert JH, et al. Comparison of 3 Methods to Induce Acute Pulmonary Hypertension in Pigs. Comp Med 2009;59:280-6.

51. McLean RF, Prielipp RC, Rosenthal MH, et al. Vasodilator therapy in microembolic porcine pulmonary hypertension. Anesth Analg 1990;71:35-41.

52. Prielipp RC, McLean R, Rosenthal MH, et al. Hemodynamic profiles of prostaglandin E1, isoproterenol, prostacyclin, and nifedipine in experimental porcine pulmonary hypertension. Crit Care Med 1991;19:60-7.

53. Krueger K, Deissler P, Coburger S, et al. How Thrombus Model Impacts the In Vitro Study of Interventional Thrombectomy Procedures. Invest Radiol 2004;39:641-8. 
54. Beam DM, Neto-Neves EM, Stubblefield WB, et al. Comparison of Isoflurane and $\alpha$-Chloralose in an Anesthetized Swine Model of Acute Pulmonary Embolism Producing Right Ventricular Dysfunction. Comp Med 2015;65:54-61.

55. Schultz J, Andersen A, Kabrhel C, et al. Catheter-based therapies in acute pulmonary embolism. EuroIntervention 2018;13:1721-7.

56. Braunwald E. Pathophysiology of heart failure. In: Braunwald E, Zipes D, Libby P, et al. editors. Heart disease: a textbook of cardiovascular medicine. Philadelphia: Saunders, 1980:453-71.

57. Voelkel NF, Quaife RA, Leinwand LA, et al. Right ventricular function and failure: report of a National Heart, Lung, and Blood Institute working group on cellular and molecular mechanisms of right heart failure. Circulation 2006;114:1883-91.

58. Rai N, Veeroju S, Schymura Y, et al. Effect of Riociguat and Sildenafil on Right Heart Remodeling and Function in Pressure Overload Induced Model of Pulmonary Arterial Banding. BioMed Res Int 2018;2018:3293584.

59. Janssen W, Schymura Y, Novoyatleva T, et al. 5-HT2B receptor antagonists inhibit fibrosis and protect from RV heart failure. BioMed Res Int 2015;2015:438403-8.

60. Wang Q, Chen K, Lin H, et al. Induction of Right Ventricular Failure by Pulmonary Artery Constriction and Evaluation of Right Ventricular Function in Mice. J Vis Exp 2019. doi:10.3791/59431.

61. Andersen S, Schultz JG, Holmboe S, et al. A Pulmonary Trunk Banding Model of Pressure Overload Induced Right Ventricular Hypertrophy and Failure. J Vis Exp 2018. doi: $10.3791 / 58050$.

62. Hirata M, Ousaka D, Arai S, et al. Novel Model of Pulmonary Artery Banding Leading to Right Heart Failure in Rats. Biomed Res Int 2015;2015:753210.

63. Schou UK, Peters CD, Kim SW, et al. Characterization of a rat model of right-sided heart failure induced by pulmonary trunk banding. J Exp Anim Sci 2007;43:237-54.

64. Mendes-Ferreira P, Santos-Ribeiro D, Adão R, et al. Distinct right ventricle remodeling in response to pressure overload in the rat. Am J Physiol Heart Circ Physiol 2016;311:H85-95.

65. Borgdorff MA, Bartelds B, Dickinson MG, et al. Sildenafil enhances systolic adaptation, but does not prevent diastolic dysfunction, in the pressure-loaded right ventricle. Eur J Heart Fail 2012;14:1067-74.

66. LekanneDeprez RH, van den Hoff MJ, de Boer PA, et al. Changing Patterns of Gene Expression in the
Pulmonary Trunk-banded Rat Heart. J Mol Cell Cardiol 1998;30:1877-88.

67. Gupta SC, Varian KD, Bal NC, et al. Pulmonary artery banding alters the expression of $\mathrm{Ca} 2+$ transport proteins in the right atrium in rabbits. Am J Physiol Heart Circ Physiol 2009;296:H1933-9.

68. Nielsen EA, Okumura K, Sun M, et al. Regional septal hinge-point injury contributes to adverse biventricular interactions in pulmonary hypertension. Physiol Rep 2017;5:e13332.

69. Roldan Ramos S, Pieles G, Hui W, et al. A rabbit model of progressive chronic right ventricular pressure overload. Interact Cardiovasc Thorac Surg 2018;26:673-80.

70. Laks MM, Morady F, Swan HJ. Canine right and left ventricular cell and sarcomere lengths after banding the pulmonary artery. Circ Res 1969;24:705-10.

71. Hsieh CM, Mishkel GJ, Cardoso PF, et al. Production and reversibility of right ventricular hypertrophy and right heart failure in dogs. Ann Thorac Surg 1992;54:104-10.

72. Gluck L, Tainer NS, Stern H, et al. Experimental Cardiac Hypertrophy: Concentrations of RNA in the Ventricles. Science 1964;144:1244-5.

73. Le Bret E, Bonhoeffer P, Folliguet TA, et al. A new percutaneously adjustable, thoracoscopically implantable, pulmonary artery banding: an experimental study. Ann Thorac Surg 2001;72:1358-61.

74. Lambert V, Capderou A, Le Bret E, et al. Right ventricular failure secondary to chronic overload in congenital heart disease: an experimental model for therapeutic innovation. J Thorac Cardiovasc Surg 2010;139:1197-204, 1204.e1.

75. Corno AF, Sekarski N, Bernath MA, et al. Pulmonary artery banding: long-term telemetric adjustment. Eur J Cardiothorac Surg 2003;23:317-22.

76. Hyldebrandt JA, Agger P, Sivén E, et al. Effects of milrinone and epinephrine or dopamine on biventricular function and hemodynamics in right heart failure after pulmonary regurgitation. Am J Physiol Heart Circ Physiol 2015;309:H860-6.

77. Kay JM, Harris P, Heath D. Pulmonary hypertension produced in rats by ingestion of Crotalaria spectabilis seeds. Thorax 1967;22:176-9.

78. Gomez-Arroyo JG, Farkas L, Alhussaini A, et al. The monocrotaline model of pulmonary hypertension in perspective. Am J Physiol Lung Cell Mol Physiol 2012;302:L363-9.

79. Hessel MH, Steendijk P, den Adel B, et al. Characterization of right ventricular function after monocrotaline-induced pulmonary hypertension in the intact rat. Am J Physiol 
Heart Circ Physiol 2006;291:H2424-30.

80. Coste F, Guibert C, Magat J, et al. Chronic hypoxia aggravates monocrotaline-induced pulmonary arterial hypertension: a rodent relevant model to the human severe form of the disease. Respir Res 2017;18:47.

81. Okada K, Tanaka Y, Bernstein M, Zhang W, et al. Pulmonary hemodynamics modify the rat pulmonary artery response to injury. A neointimal model of pulmonary hypertension. Am J Pathol 1997;151:1019-25.

82. Tada Y, Laudi S, Harral J, et al. Murine Pulmonary Response to Chronic Hypoxia is Strain Specific. Exp Lung Res 2008;34:313-23.

83. Rabinovitch $M$, Gamble W, Nadas AS, et al. Rat pulmonary circulation after chronic hypoxia: hemodynamic and structural features. Am J Physiol 1979;236:H818-27.

84. Stenmark KR, Fasules J, Hyde DM, et al. Severe pulmonary hypertension and arterial adventitial changes in newborn calves at 4,300 m. J Appl Physiol (1985) 1987;62:821-30.

85. Vitali SH, Hansmann G, Rose C, et al. The Sugen 5416/ Hypoxia Mouse Model of Pulmonary Hypertension Revisited: Long-Term Follow-Up. Pulm Circ 2014;4:619-29.

86. Taraseviciene-Stewart L, Kasahara Y, Alger L, et al. Inhibition of the VEGF receptor 2 combined with chronic hypoxia causes cell death-dependent pulmonary endothelial cell proliferation and severe pulmonary hypertension. FASEB J 2001;15:427-38.

87. de Raaf MA, Schalij I, Gomez-Arroyo J, et al. SuHx rat model: partly reversible pulmonary hypertension and progressive intima obstruction. Eur Respir J 2014;44:160-8.

88. Sato K, Webb S, Tucker A, et al. Factors influencing the idiopathic development of pulmonary hypertension in the fawn hooded rat. Am Rev Respir Dis 1992;145:793-7.

89. Bonnet S, Michelakis ED, Porter CJ, et al. An abnormal mitochondrial-hypoxia inducible factor-1alpha-Kv channel pathway disrupts oxygen sensing and triggers pulmonary arterial hypertension in fawn hooded rats: similarities to human pulmonary arterial hypertension. Circulation 2006;113:2630-41.

90. Le Cras TD, Kim DH, Markham NE, et al. Early abnormalities of pulmonary vascular development in the Fawn-Hooded rat raised at Denver's altitude. Am J Physiol Lung Cell Mol Physiol 2000;279:L283-91.

91. Taraseviciene-Stewart L, Nicolls MR, Kraskauskas D, et al. Absence of T cells confers increased pulmonary arterial hypertension and vascular remodeling. Am J Respir Crit
Care Med 2007;175:1280-9.

92. Arias-Loza P-A, Jung P, Abeßer M, et al. Development and Characterization of an Inducible Rat Model of Chronic Thromboembolic Pulmonary Hypertension. Hypertension 2016;67:1000-5.

93. Mercier O, Tivane A, Dorfmüller P, et al. Piglet model of chronic pulmonary hypertension. Pulm Circ 2013;3:908-15.

94. Voss S, Nef MH, Rolf A, et al. Chronic Thromboembolic Pulmonary Hypertension (CTEPH): A Pig Model. Circulation 2012;126:A15228.

95. Neto-Neves EM, Brown MB, Zaretskaia MV, et al. Chronic Embolic Pulmonary Hypertension Caused by Pulmonary Embolism and Vascular Endothelial Growth Factor Inhibition. Am J Pathol 2017;187:700-12.

96. Wang S, Ye L, Hong $\mathrm{H}$, et al. A neonatal rat model of increased right ventricular afterload by pulmonary artery banding. J Thorac Cardiovasc Surg 2017;154:1734-9.

97. Faber MJ, Dalinghaus M, Lankhuizen IM, et al. Right and left ventricular function after chronic pulmonary artery banding in rats assessed with biventricular pressure-volume loops. Am J Physiol Heart Circ Physiol 2006;291:H1580-6.

98. Bogaard HJ, Natarajan R, Henderson SC, et al. Chronic pulmonary artery pressure elevation is insufficient to explain right heart failure. Circulation 2009;120:1951-60.

99. Andersen S, Schultz JG, Andersen A, et al. Effects of bisoprolol and losartan treatment in the hypertrophic and failing right heart. J Card Fail 2014;20:864-73.

100. Andersen A, Povlsen JA, Johnsen J, et al. International Journal of Cardiology 2016;223:674-80.

101.Le Bret E, Lupoglazoff JM, Borenstein N, et al. Cardiac "fitness" training: an experimental comparative study of three methods of pulmonary artery banding for ventricular training. Ann Thorac Surg 2005;79:198-203.

102. Solis E, Heck CF, Seward JB, et al. Percutaneously adjustable pulmonary artery band. Ann Thorac Surg 1986;41:65-9.

103.Park SC, Griffith BP, Siewers RD, et al. A percutaneously adjustable device for banding of the pulmonary trunk. Int J Cardiol 1985;9:477-84.

104. Katayama H, Krzeski R, Frantz EG, et al. Induction of right ventricular hypertrophy with obstructing balloon catheter. Nonsurgical ventricular preparation for the arterial switch operation in simple transposition. Circulation 1993;88:1765-9.

105. Stenmark KR, Meyrick B, Galiè N, et al. Animal models of pulmonary arterial hypertension: the hope for etiological 
discovery and pharmacological cure. Am J Physiol Lung Cell Mol Physiol 2009;297:L1013-32.

106. Burke DL, Frid MG, Kunrath CL, et al. Sustained hypoxia promotes the development of a pulmonary artery-specific chronic inflammatory microenvironment. Am J Physiol Lung Cell Mol Physiol 2009;297:L238-50.

107. Naeije R, Dedobbeleer C. Pulmonary hypertension and the right ventricle in hypoxia. Exp Physiol 2013;98:1247-56.

108. Simonneau G, Montani D, Celermajer DS, et al. Haemodynamic definitions and updated clinical classification of pulmonary hypertension. Eur Respir J 2019;53:1801913.

109. Guignabert C, Alvira CM, Alastalo TP, et al. Tie2mediated loss of peroxisome proliferator-activated receptor- $\gamma$ in mice causes PDGF receptor- $\beta$-dependent pulmonary arterial muscularization. Am J Physiol Lung Cell Mol Physiol 2009;297:L1082-90.

110.Legchenko E, Chouvarine P, Borchert P, et al. PPAR $\gamma$ agonist pioglitazone reverses pulmonary hypertension and prevents right heart failure via fatty acid oxidation. Sci Transl Med 2018;10:eaao0303.

111. Wilson DW, Segall HJ, Pan LC, et al. Mechanisms and Pathology of Monocrotaline Pulmonary Toxicity. Crit Rev Toxicol 1992;22:307-25.

112. Campian ME, Hardziyenka M, de Bruin K, et al. Early inflammatory response during the development of right ventricular heart failure in a rat model. Eur J Heart Fail 2010;12:653-8.

113.Akhavein F, St-Michel EJ, Seifert E, et al. Decreased left ventricular function, myocarditis, and coronary arteriolar medial thickening following monocrotaline administration in adult rats. J Appl Physiol (1985) 2007;103:287-95.

114.Bogaard HJ, Legchenko E, Chaudhary KR, et al. Emphysema Is-at the Most-Only a Mild Phenotype in the Sugen/Hypoxia Rat Model of Pulmonary Arterial Hypertension. Am J Respir Crit Care Med 2019;200:1447-50.

115. Kojonazarov B, Hadzic S, Ghofrani HA, et al. Reply to Bogaard et al.: Emphysema Is-at the Most-Only a Mild Phenotype in the Sugen/Hypoxia Rat Model of Pulmonary Arterial Hypertension. Am J Respir Crit Care Med 2019;200:1450-2.

116. Oka M, Homma N, Taraseviviene-Stewart L, et al. Rho kinase-mediated vasoconstriction is important in severe occlusive pulmonary arterial hypertension in rats. Circ Res 2007;100:923-9.

117.Abe K, Toba M, Alzoubi A, et al. Formation of plexiform lesions in experimental severe pulmonary arterial hypertension. Circulation 2010;121:2747-54.

118. Bogaard HJ, Legchenko E, et al. The Adult SpragueDawley Sugen-Hypoxia Rat Is Still “the One:” A Model of Group 1 Pulmonary Hypertension: Reply to Le Cras and Abman. Am J Respir Crit Care Med 2020;201:621-4.

119.Happé CM, de Raaf MA, Rol N, et al. Pneumonectomy combined with SU5416 induces severe pulmonary hypertension in rats. Am J Physiol Lung Cell Mol Physiol 2016;310:L1088-97.

120. Tian W, Jiang $X$, Tamosiuniene $\mathrm{R}$, et al. Blocking macrophage leukotriene b4 prevents endothelial injury and reverses pulmonary hypertension. Sci Transl Med 2013;5:200ra117-7.

121. Ciuclan L, Bonneau O, Hussey M, et al. A Novel Murine Model of Severe Pulmonary Arterial Hypertension. Am J Respir Crit Care Med 2011;184:1171-82.

122. Sztuka K, Jasińska-Stroschein M. Animal models of pulmonary arterial hypertension: A systematic review and meta-analysis of data from 6126 animals. Pharmacol Res 2017;125:201-14.

123.Lang IM, Madani M. Update on chronic thromboembolic pulmonary hypertension. Circulation 2014;130:508-18.

124. Gerges C, Gerges M, Friewald R, et al. Microvascular Disease in Chronic Thromboembolic Pulmonary Hypertension: Hemodynamic Phenotyping and Histomorphometric Assessment. Circulation 2020;141:376-86.

125. Dorfmüller P, Günther S, Ghigna M-R, et al. Microvascular disease in chronic thromboembolic pulmonary hypertension: a role for pulmonary veins and systemic vasculature. Eur Respir J 2014;44:1275-88.

126. Wilkens H, Lang I, Behr J, et al. Chronic thromboembolic pulmonary hypertension (CTEPH): updated

Recommendations of the Cologne Consensus Conference 2011. Int J Cardiol 2011;154 Suppl 1:S54-60.

127.Kim H, Yung GL, Marsh JJ, et al. Endothelin mediates pulmonary vascular remodelling in a canine model of chronic embolic pulmonary hypertension. Eur Respir J 2000;15:640-8.

128. Moser KM, Cantor JP, Olman M, et al. Chronic pulmonary thromboembolism in dogs treated with tranexamic acid. Circulation 1991;83:1371-9.

129.Moser KM, Guisan M, Bartimmo EE, et al. In vivo and post mortem dissolution rates of pulmonary emboli and venous thrombi in the dog. Circulation 1973;48:170-8.

130.Marsh JJ, Konopka RG, Lang IM, et al. Suppression of thrombolysis in a canine model of pulmonary embolism. Circulation 1994;90:3091-7. 
131. Shimazaki Y, Blackstone EH, Kirklin JW. The natural history of isolated congenital pulmonary valve incompetence: surgical implications. Thorac Cardiovasc Surg 1984;32:257-9.

132.Apitz C, Webb GD, Redington AN. Tetralogy of Fallot. Lancet 2009;374:1462-71.

133. Rodés-Cabau J, Taramasso M, O'Gara PT. Diagnosis and treatment of tricuspid valve disease: current and future perspectives. Lancet 2016;388:2431-42.

134.van der Feen DE, Bartelds B, de Boer RA, et al. Pulmonary arterial hypertension in congenital heart disease: translational opportunities to study the reversibility of pulmonary vascular disease. Eur Heart J 2017;38:2034-41.

135. Bossers GPL, Hagdorn QAJ, Ploegstra MJ, et al. Volume load-induced right ventricular dysfunction in animal models: insights in a translational gap in congenital heart disease. Eur J Heart Fail 2018;20:808-12.

136. Bauman RP, Rembert JC, Greenfield JC. Myocardial blood flow in awake dogs with chronic tricuspid regurgitation. Basic Res Cardiol 1998;93:63-9.

137. Borgdorff MAJ, Bartelds B, Dickinson MG. Distinct Loading Conditions Reveal Various Patterns of Right Ventricular Adaptation. Am J Physiol Heart Circ Physiol 2013;305:H354-64.

138.van Albada ME, Schoemaker RG, Kemna MS, et al. The role of increased pulmonary blood flow in pulmonary arterial hypertension. Eur Respir J 2005;26:487-93.

139.van der Feen DE, Weij M, Smit-van Oosten A, et al. Shunt Surgery, Right Heart Catheterization, and Vascular Morphometry in a Rat Model for Flow-induced Pulmonary Arterial Hypertension. J Vis Exp 2017;(120):55065.

140. Dickinson MG, Bartelds B, Molema G, et al. Egr1 expression during neointimal development in flowassociated pulmonary hypertension. Am J Pathol 2011;179:2199-209.

141. Van der Feen DE, Kurakula K, Tremblay E, et al. Multicenter Preclinical Validation of BET Inhibition for the Treatment of Pulmonary Arterial Hypertension. Am J Respir Crit Care Med 2019;200:910-20.

142.van Albada ME, Bartelds B, Wijnberg H, et al. Gene expression profile in flow-associated pulmonary arterial hypertension with neointimal lesions. Am J Physiol Lung Cell Mol Physiol 2010;298:L483-91.

143. Dickinson MG, Kowalski PS, Bartelds B, et al. A critical role for Egr-1 during vascular remodelling in pulmonary arterial hypertension. Cardiovasc Res 2014;103:573-84.

144. Rungatscher A, Linardi D, Milani E, et al. Chronic overcirculation-induced pulmonary arterial hypertension in aorto-caval shunt. Microvasc Res 2014;94:73-9.

145. Mercier O, Sage E, de Perrot M, et al. Regression of flow-induced pulmonary arterial vasculopathy after flow correction in piglets. J Thorac Cardiovasc Surg 2009;137:1538-46.

146. Reddy VM, Meyrick B, Wong J, et al. In utero placement of aortopulmonary shunts. A model of postnatal pulmonary hypertension with increased pulmonary blood flow in lambs. Circulation 1995;92:606-13.

147. Boehme J, Sun X, Tormos KV, et al. Pulmonary artery smooth muscle cell hyperproliferation and metabolic shift triggered by pulmonary overcirculation. Am J Physiol Heart Circ Physiol 2016;311:H944-57.

148. Aggarwal S, Gross CM, Kumar S, et al. Attenuated vasodilatation in lambs with endogenous and exogenous activation of cGMP signaling: role of protein kinase $\mathrm{G}$ nitration. J Cell Physiol 2011;226:3104-13.

149. Johnson Kameny R, Datar SA, Boehme JB, et al. Ovine Models of Congenital Heart Disease and the Consequences of Hemodynamic Alterations for Pulmonary Artery Remodeling. Am J Respir Cell Mol Biol 2019;60:503-14.

150. Oishi P, Sharma S, Grobe A, et al. Alterations in cGMP, soluble guanylate cyclase, phosphodiesterase 5 , and B-type natriuretic peptide induced by chronic increased pulmonary blood flow in lambs. Pediatr Pulmonol 2007;42:1057-71.

151. Grobe AC, Wells SM, Benavidez E, et al. Increased oxidative stress in lambs with increased pulmonary blood flow and pulmonary hypertension: role of NADPH oxidase and endothelial NO synthase. Am J Physiol Lung Cell Mol Physiol 2006;290:L1069-77.

152.Szabó G, Soós P, Bährle S, et al. Adaptation of the right ventricle to an increased afterload in the chronically volume overloaded heart. Ann Thorac Surg 2006;82:989-95.

153. Bartelds B, Borgdorff MA, Smit-van Oosten A, et al. Differential responses of the right ventricle to abnormal loading conditions in mice: pressure vs. volume load. Eur J Heart Fail 2011;13:1275-82.

154.Liu Z, Hilbelink DR, Gerdes AM. Regional changes in hemodynamics and cardiac myocyte size in rats with aortocaval fistulas. 2. Long-term effects. Circ Res 1991;69:59-65.

155.Modesti PA, Vanni S, Bertolozzi I, et al. Different growth factor activation in the right and left ventricles in experimental volume overload. Hypertension 2004;43:101-8. 
156.Dickinson MG, Bartelds B, Borgdorff MAJ, et al. The role of disturbed blood flow in the development of pulmonary arterial hypertension: lessons from preclinical animal models. Am J Physiol Lung Cell Mol Physiol 2013;305:L1-14.

157.Agger P, Hyldebrandt JA, Nielsen EA, et al. A novel porcine model for right ventricular dilatation by external suture plication of the pulmonary valve leaflets--practical and reproducible. Interact Cardiovasc Thorac Surg 2010;10:962-6.

158. Bove T, Bouchez S, De Hert S, et al. Acute and chronic effects of dysfunction of right ventricular outflow tract components on right ventricular performance in a porcine model: implications for primary repair of tetralogy of fallot. J Am Coll Cardiol 2012;60:64-71.

159. Ersboell M, Vejlstrup N, Nilsson JC, et al. Percutaneous pulmonary valve replacement after different duration of free pulmonary regurgitation in a porcine model: effects on the right ventricle. Int J Cardiol 2013;167:2944-51.

160. Kjaergaard J, Iversen KK, Vejlstrup NG, et al. Effects of chronic severe pulmonary regurgitation and percutaneous valve repair on right ventricular geometry and contractility assessed by tissue Doppler echocardiography. Echocardiography 2010;27:854-63.

161.Kuehne T, Saeed M, Gleason K, et al. Effects of pulmonary insufficiency on biventricular function in the developing heart of growing swine. Circulation 2003;108:2007-13.

162. Smith J, Goetze JP, Søndergaard L, et al. Myocardial hypertrophy after pulmonary regurgitation and valve implantation in pigs. Int J Cardiol 2012;159:29-33.

163. Gray R, Greve G, Chen R et al. Right ventricular myocardial responses to chronic pulmonary regurgitation in lambs: disturbances of activation and conduction. Pediatr Res 2003;54:529-35.

164. Reddy S, Zhao M, Hu DQ, et al. Physiologic and molecular characterization of a murine model of right ventricular volume overload. Am J Physiol Heart Circ Physiol 2013;304:H1314-27.

165. Vonk-Noordegraaf A, Haddad F, Chin KM, et al. Right Heart Adaptation to Pulmonary Arterial Hypertension: Physiology and Pathobiology. J Am Coll Cardiol 2013;62(25):D22-D33.

166. Ruiter G, de Man FS, Schalij I et al. Reversibility of the monocrotaline pulmonary hypertension rat model. Eur Respir J 2013;42:553-6.

167. Tanaka Y, Schuster DP, Davis EC, et al. The role of vascular injury and hemodynamics in rat pulmonary artery remodeling. J Clin Invest 1996;98:434-42.

168.Lakshminrusimha S, Wiseman D, Black SM, et al. The role of nitric oxide synthase-derived reactive oxygen species in the altered relaxation of pulmonary arteries from lambs with increased pulmonary blood flow. Am J Physiol Heart Circ Physiol 2007;293:H1491-7.

169. Fratz S, Meyrick B, Ovadia B, et al. Chronic endothelin A receptor blockade in lambs with increased pulmonary blood flow and pressure. Am J Physiol Lung Cell Mol Physiol 2004;287:L592-7.

170.Johnson RC, Datar SA, Oishi PE, et al. Adaptive right ventricular performance in response to acutely increased afterload in a lamb model of congenital heart disease: evidence for enhanced Anrep effect. Am J Physiol Heart Circ Physiol 2014;306:H1222-30.

171. Bonnet S, Provencher S, Guignabert C, et al. Translating Research into Improved Patient Care in Pulmonary Arterial Hypertension. Am J Respir Crit Care Med. 2017;195(5):583-95.

172. West J, Fagan K, Steudel W, et al. Pulmonary Hypertension in Transgenic Mice Expressing a DominantNegative BMPRII Gene in Smooth Muscle. Circ Res 2004;94:1109-14.

173. Calvier L, Boucher P, Herz J, Hansmann G. LRP1 Deficiency in Vascular SMC Leads to Pulmonary Arterial Hypertension That Is Reversed by PPAR $\gamma$ Activation. Circ Res 2019;124:1778-85.

174.Hansmann G, Wagner RA, Schellong S, et al. Pulmonary arterial hypertension is linked to insulin resistance and reversed by peroxisome proliferator-activated receptorgamma activation. Circulation 2007;115:1275-84.

175. Calvier L, Chouvarine P, Legchenko E, et al. PPAR $\gamma$ Links BMP2 and TGFß1 Pathways in Vascular Smooth Muscle Cells, Regulating Cell Proliferation and Glucose Metabolism. Cell Metab. 2017;25:1118-34.e7.

176. Hansmann G, de Jesus Perez VA, Alastalo TP, et al. An antiproliferative BMP-2/PPARgamma/apoE axis in human and murine SMCs and its role in pulmonary hypertension. J Clin Invest 2008;118:1846-57.

177.Hansmann G, Calvier L, Risbano MG, et al. Activation of the Metabolic Master Regulator PPAR $\gamma$ : A Potential PIOneering Therapy for Pulmonary Arterial Hypertension. Am J Respir Cell Mol Biol 2020;62:143-56.

178. Agrawal V, Lahm T, Hansmann G, et al. Molecular mechanisms of right ventricular dysfunction in pulmonary 
arterial hypertension: focus on the coronary vasculature, sex hormones, and glucose/lipid metabolism. Cardiovasc Diagn Ther 2020;10:1522-1540.

179. Heinzel FR, Hegemann N, HohendannerF, et al. Left ventricular dysfunction in heart failure with preserved ejection fraction-molecular mechanisms and impact on right ventricular function. Cardiovasc Diagn Ther

Cite this article as: Andersen A, van der Feen DE, Andersen S, Schultz JG, Hansmann G, Bogaard HJ. Animal models of right heart failure. Cardiovasc Diagn Ther 2020;10(5):1561-1579. doi: $10.21037 /$ cdt-20-400
2020;10:1541-60.

180. Inampudi C, Tedford RJ, Hemnes AR, et al. Treatment of right ventricular dysfunction and heart failure in pulmonary arterial hypertension. Cardiovasc Diagn Ther 2020;10:1659-74.

181. Emerging Therapies for RV Dysfunction and Failure. Cardiovasc Diagn Ther 2020. 